\title{
PENDIDIKAN KEAGAMAAN PADA KOMUNITAS MUSLIM INDONESIA DI HONG KONG
}

\section{RELIGIOUS EDUCATION OF INDONESIAN MOSLEM COMMUNITY IN HONG KONG}

\author{
Rudy Harisyah Alam \\ Peneliti pada Balai Litbang Agama Jakarta \\ email: rhalam2014@gmail.com
}

Naskah diterima 10 Oktober 2016, direvisi 30 Oktober 2016, disetujui 15 November 2016

\begin{abstract}
This writing is a result of research on Religious Education of Indonesia Moslem Community in Hong Kong,to find out which institutions and what characteristics become providers of the religious education for Indonesian Moslem community in Hong Kong. This research uses explorativequalitative approach by data collection technique through a combination between individual and group interview technique, field observation, as well as document and literature study. The result of this study shows: firstly, almost a half of the Moslem community in Hong Kong is Indonesian Moslem community, they are generally come from migrant workers in non-formal sectors (such as maid) which in social, political and economical aspect they have a weak bargaining position in their life in Hong Kong. Secondly, the Indonesian Moslem Community in Hong Kong generally consists of female workers and they are not allowed taking their children or family with them, their immediate needs are guidance and educational service on religion for their own needs in the form of a non-formal religion educational service. The need on education and religion are obtained by establishing religious groups, associations or organizations which in general are not registered as an official organization in the Government of Hong Kong. Thirdly, they regularly strive to meet their needs on religious guidance and education by holding a routine group religious guidance held Sundays, as the day is holiday which in general is granted to the majority of Indonesian workers.
\end{abstract}

Keywords: Religious Education, Indonesian Moslem Community, Hong Kong

\section{Abstrak}

Tulisan ini merupakan hasil penelitian tentang Pendidikan Keagamaan pada Komunitas Muslim Indonsesia di Hong Kong, yang bertujuan untuk mengetahui institusi-institusi dan karakteristik apa yang menjadi penyedia layanan pendidikan keagamaan komunitas Muslim Indonesia di Hongkong. Penelitian ini menggunakan pendekatan kualitatif-eksploratif dengan teknik pengumpulan data melalui mengombinasikan teknik wawancara individual dan kelompok, observasi lapangan, serta studi dokumen dan literatur. Hasil setudi ini ditemukan antara lain: pertama, hampir separuh dari komunitas Muslim di Hong Kong adalah kaum Muslim Indonesia, umumnya mereka berasal dari kalangan pekerja migran pada sektor non formal (pembantu rumah tangga) yang secara sosial, politik dan ekonomi tidak memiliki daya tawar yang kuat dalam kehidupan di negara Hong Kong. Kedua, Komunitas Muslim Indonesia di Hong Kong umumnya adalah pekerja wanita dan tidak diperkenankan membawa anak atau keluarga, kebutuhan mendesak yang mereka hadapi adalah layanan bimbingan dan pendidikan agama bagi diri mereka sendiri, berupa layanan pendidikan keagamaan non-formal. Kebutuhan pendidikan dan keagamaan diperoleh dengan cara membentuk kelompok, perkumpulan atau organisasi keagamaan yang umumnya tidak terdaftar sebagai organisasi resmi pada pemerintah Hong Kong. Ketiga, secara reguler mereka berupaya memenuhi kebutuhan akan bimbingan dan pendidikan keagamaan melalui pengajian rutin yang diadakan setiap hari Minggu, sesuai waktu libur yang umumnya tersedia bagi mayoritas pekerja Indoensia.

Kata Kunci Pendidikan Keagamaaan, Komunitas Muslim Indonesia, Hong kong 


\section{PENDAHULUAN}

Hong Kong adalah sebuah wilayah yang terbentuk pada era kolonialisme Inggris pada abad ke 19. Terletak di selatan China, Hong Kong pada masa itu telah dijadikan Inggris sebagai pelabuhan dan pusat perdagangan di wilayah tersebut. Secara geografis Hong Kong terdiri dari Pulau Hong Kong (Hong Kong Island), yang diserahkan pemerintah China ke Inggris pada 1841, Semenanjung Kowloon (Kowloon Peninsula), yang juga diserahkan pada 1860, dan terakhir Daerah Baru (New Territories) yang disewakan China ke Inggris selama 99 tahun sejak 1898. Batas jatuh tempo sewa itu adalah pada 1 Juli 1997. Meski yang berstatus sewa dan karena itu wajib diserahkan lagi oleh Inggris ke China hanyalah Daerah Baru, namun dalam negosiasi penyerahan kembali akhirnya disepakati bahwa ketiga wilayah itu merupakan satu kesatuan, dan secara keseluruhan akan dikembalikan ke pemerintah Republik Rakyat China (RRC). Akhirnya pada 1 Juli 1997 keseluruhan wilayah Hong Kong diserahkan pemerintah Inggris kepada pemerintah RRC1.

Hong Kong saat ini adalah kota-negara berwajah modern, yang ditandai dengan berdirinya berbagai pusat perbelanjaan, apartemen, hotel, dan gedung pencakar langit yang menjulang tinggi. Kota "beton dan kaca" itu dilengkapi dengan sarana transportasi canggih dan kompleks, yang menghubungkan hampir seluruh titik tempat di Hong Kong, dengan berbagai jenis moda terpadu, mulai dari bus, trem (light

${ }^{1}$ Mark Bray and Ramsey Koo. 2005. Education and Society in Hong Kong and Macao: Comparative Perspectives on Continuity and Change. Second edition. Dordrecht, Netherlands: Springer, h. 4 train), kereta api massal (Mass Transit Railway, MTR), hingga kereta api cepat. Ditambah lagi dengan jembatan dan terowongan bawah laut (kanal) yang membuat seluruh pulau terhubung satu sama lain, serta terkoneksinya Hong Kong dengan daratan china.

Secara pemerintahan, Hong Kong dikenal dengan istilah "satu negara, dua sistem" ("one country, two systems"). Artinya, meski Hong Kong termasuk sebagai bagian dari negara China, Hong Kong memiliki kewenangan penuh untuk menjalankan pemerintahan dan mengatur urusan warganya, termasuk sistem hukum, keuangan dan pendidikan. Sementara China secara resmi menganut sistem sosialis, Hong Kong secara resmi menjalankan sistem kapitalis. Dengan kekhususannya itu, Hong Kong disebut sebagai Daerah Pemerintahan Khusus (Special Administrative Region), yang dikelola berdasarkan Undang-Undang Dasar (Basic Law), serta dipimpin oleh seorang Kepala Eksekutif (Chief Executive). (Tentang Basic Law dan berbagai penafsiran konstitusional mengenainya, lihat $\mathrm{Fu}$, Harris, dan Young, eds.) ${ }^{2}$

Hong Kong kini dihuni lebih dari 7 juta jiwa, dengan tingkat kepadatan penduduk hampir mencapai 7.000 penduduk per kilometer persegi (Hong Kong Book Year 2014). Di wilayah tertentu, seperti Semenanjung Kowloon, tempat Pasar Mong Kong yang terkenal berada, kepadatan bahkan dapat mencapai sekitar 40.000 jiwa per kilometer persegi. Setiap hari jutaan orang turun ke

${ }^{2}$ Hualing Fu, Lison Harris, Simon N.M. Young, eds. 2007. Interpreting Hong Kong's Basic Law: The Struggle for Coherence. New York: Palgrave Macmillan 
jalan menggerakkan roda perekonomian di Hong Kong. Ratusan ribu, bahkan mungkin jutaan, dari mereka lalu lalang menyusuri jalan-jalan di Hong Kong, baik penduduk setempat, turis maupun pekerja migran dari mancanegara. Sebagian mereka berjalan kaki, menempuhjarak sedikitnya 5 kilometer per hari; sebagian lainnya menggunakan bus, trem, atau MTR dan kereta api cepat untuk menjangkau tempat-tempat yang lebih jauh.

Di antara sekitar 7 juta lebih penduduk Hong Kong, di sana terdapat sekitar 300.000 penduduk Muslim (sekitar 4 persen dari total populasi). Dari sekitar 300.000 penduduk Muslim itu, sekitar 40.000 merupakan etnis China, 30.000 adalah orang Pakistan, dan sekitar 150.0000 adalah warga Indonesia! Sisanya, berasal dari berbagai negara seperti India, Malaysia, negara-negara Timur Tengah dan Afrika (Hong Kong Yearbook 2014). Dengan demikian, jumlah warga Muslim dari Indonesia yang tinggal di Hong Kong mencapai separuh dari total penduduk Muslim di negara itu, atau sekitar 2 persen dari total jumlah penduduk Hong Kong.

Sejumlah pertanyaan menarik segera mengemuka: Siapakah kaum Muslim Indonesia yang menjadi separuh bagian jumlah penduduk Muslim di Hong Kong? Kehidupan keagamaan seperti apa yang mereka jalani di kota-negara yang modern itu? Bagaimana mereka menunaikan ritual keagamaan mereka, seperti salat, puasa, zakat dan pergi haji ke Makkah? Berapa banyak orang yang meninggalkan Islam dan berpindah kepada keyakinan lain, atau sebaliknya adakah dan berapa banyak orang-orang yang berpindah memeluk Islam, dan siapa yang memfasilitasi mereka? Bagaimana mereka memenuhi kebutuhan akan pendidikan agama dan keagamaan? Siapa atau institusi-institusi apa yang menjadi penyedia layanan kehidupan keagamaan maupun pendidikan agama dan keagamaan mereka?

Meski pertanyaan-pertanyaan di atas penting dan menarik untuk dijawab, tulisan ini hanya akan membatasi pada aspek pendidikan agama dan keagamaan yang dijalani komunitas Muslim Indonesia di Hong Kong, sementara aspek kehidupan keagamaan yang lebih luas hanya akan disinggung sekilas. Sebagaimana akan dijelaskan, perhatian terutama akan lebih diberikan pada pendidikan keagamaan non-formal, mengingat komunitas pekerja migran Indonesia merupakan porsi terbesar dari keseluruhan komunitas Muslim Indonesia di Hong Kong.

Secara khusus, tulisan ini difokuskan untuk menjawab pertanyaan: Institusiinstitusi apa yang menjadi penyedia layanan guna memenuhi kebutuhan pendidikan keagamaan komunitas Muslim Indonesia di Hongkong? Bagaimana karakteristik penyediaan layanan pendidikan keagamaan tersebut? Pada bagian akhir tulisan ini, penulis akan memaparkan sejumlah rekomendasi terkait hasil penelitian ini.

\section{METODOLOGI PENELITIAN}

Penelitian ini menggunakan pendekatan kualitatif-eksploratif. Ada sejumlah perspektif yang dapat digunakan untuk memahami kehidupan keagamaan di Hong Kong, seperti perspektif multikulturalisme dan teori pasar keagamaan. Namun, peneliti mencoba "menunda" sementara waktu perspektif-perspektif itu agar peneliti dapat mengeskplorasi secara natural fenomena 
kehidupan keagamaan, khususnya pendidikan keagamaan, kaum Muslim di sana.

Penelitian lapangan berlangsung dari 17 Desember hingga 23 Desember 2015. Pengumpulan data dilakukan dengan mengombinasikan teknik wawancara individual dan kelompok, observasi, serta studi dokumen dan literatur. Narasumber penelitian ini mencakup pejabat di Konsulat Jenderal Republik Indonesia (KJRI) Hong Kong, yang mewakili konsul Penerangan Sosial dan Budaya (Pensosbud), konsuler kepala, serta konsul polisi. Selain itu, wawancara dilakukan terhadap sejumlah pihak, antara lain pengurus Islamic Union of Hong Kong (IUHK), pengurus Dompet Dhuafa cabang Hong Kong, pengurus LPTQ Dompet Dhuafa cabang Hong Kong, pekerja migran Indonesia yang tergabung dalam Nahdlatul Ulama (NU) cabang Hong Kong dan organisasi-organisasi keislaman lainnya, dan akademisi di Hong Kong Institute of Education (HKIE) di Tai Po. Observasi dilakukan di tempat-tempat aktivitas keagamaan dan pendidikan keagamaan berlangsung, antara lain Masjid Ammar di Distrik Wan Chai, Masjid Kowloon di Tsim Sha Tsui Distrik Yau Tsim Mong, Musholla Al Falah di KJRI Hong Kong, serta di Taman Victoria, Causeway Bay.

\section{HASIL DAN PEMBAHASAN}

\section{Lansekap Keagamaan di Hong Kong}

Sebelum lebih jauh membahas soal pendidikan keagamaan kaum Muslim Indonesia di Hong Kong, ada baiknya kita terlebih dahulu menempatkan Islam dan kaum Muslim dalam konteks kehidupan keagamaan secara umum di Hong Kong. Professor Wai-Yip Ho, dosen sosiologi di Hong Kong Institute of Education, menggambarkan secara ringkas kehidupan keagamaan di Hong Kong sebagai berikut:

In general, from the time of British colonial rule to the present post-colonial period, Hong Kong has been viewed as an economic city. Religion, if not an unimportant aspect of mainstream society, is usually placed in the private realm of individual choice and on the margins of Hong Kong's historical and economic development ${ }^{3}$.

Seorang sarjana lainnya, Paul o'Connor, dosen antropologi di Chinese University of Hong Kong, mengawali tulisan dalam bukunya, Islam in Hong Kong, tentang absennya Islam dari imajinasi kebanyakan orang mengenai Hong Kong sebagai berikut:

When we think of Hong Kong, Islam is not something that springs to mind. Popular images of Hong Kong portray hyper-modern skyscrapers, Chinese signs in bright neon, a place of commercial and gastronomic delights. The Hong Kong that is popularly imagined evokes an association of dynamic cultural fusion, the exotic yet familiar, a cocktail of tradition and innovation. Islam does not share these associations ${ }^{4}$.

Meski secara umum agama masuk dalam ranah privat, namun bukan berarti ia absen sama sekali dari kehidupan publik masyarakat Hong Kong. Seperti diakui pula oleh Ho, kelompok-kelompok keagamaan,

${ }^{3}$ Wai-Yip Ho. 2014. British Raj to China's Hong Kong: The rise of madrasas for ethnic Muslim youth. Modern Asian Studies 48, 2 : h. 404.

${ }^{4}$, Peter 'O Connor. 2012. Islam in Hong Kong: Muslims and Everyday Life in China's World City. E-book. Hong Kong: Hong Kong University Press, h. 18 
baik yang dikelola para misionaris dari Barat maupun organisasi charitas masyarakat pribumi China (dan juga kita dapat tambahkan organisasi-organisasi Islam karena Ho tidak menyebutnya) memainkan peran proaktif dalam menyediakan berbagai layanan sosial, seperti layanan bagi kaum miskin, perawatan medis, dan pendidikan bagi seluruh lapisan masyarakat. ${ }^{5}$

Pemerintah Hong Kong sendiri, berdasarkan konstitusinya, Basic Law, menjamin kemerdekaan beragama penduduknya, baik penduduk tetap maupun penduduk tidak tetap. Pasal 32 Basic Law menyebutkan: Hong Kong residents shall have freedom of conscience; Hong Kong residents shall have freedom of religious belief and freedom to preach and to conduct and participate in religious activities in public.

Berkat jaminan kebebasan beragama itu, beragam agama tumbuh dan berkembang di Hong Kong, seperti Buddhisme dan Taoisme, yang masing-masing dianut oleh sekitar 1 juta lebih penduduk Hong Kong dewasa ini. Selain itu, ada pula Konfusianisme, yang sejak tahun 2014, pemerintah Hong Kong menetapkan setiap hari minggu ketiga bulan September sebagai Hari Khong $\mathrm{Hu} \mathrm{Cu}$, untuk merayakan kelahiran Khong $\mathrm{Hu} \mathrm{Cu} .{ }^{6}$

Di samping itu, berkembang pula penganut agama Kristen (Katolik dan Protestan), yang secara keseluruhan berjumlah sekitar 870.000 penduduk, atau hampir mencapai sekitar 12 persen dari total penduduk Hong Kong. Komunitas

${ }^{5}$ Wai-Yip Ho. 2014. British Raj to China's Hong Kong: The rise of madrasas for ethnic Muslim youth. Modern Asian Studies 48, 2 : h. 405

${ }^{6} \mathrm{HKSAR}$ Government, Information Services Department. 2014. Hong Kong Year Book 2014. Hong Kong: Government Logistics Department, h. 336
Protestan sendiri tercatat sekitar 500.000 orang, yang terbagi ke dalam 70 denominasi dan sedikitnya 1.500 kongregasi. Berbagai denominasi internasional hadir di sana, seperti Advent, Anglikan, Baptis, Christian and Missionary Alliance, Evangelical Free, Holiness, Lutheran, Methodis, Pentakosta dan Salvation Army. Selain itu, ada pula komunitas Protestan lokal, seperti Church of Christ in China, True Jesus Church, dan Local Church, yang umumnya dikenal sebagai Little Flock. Adapun komunitas Katolik, yang berjumlah sekitar 374.000 orang, dilayani oleh sebanyak 301 pastur, 69 biarawan, dan 491 biarawati. Ada 51 parises, yang terdiri atas 40 gereja, $31 \mathrm{kapel}$, dan 26 aula untuk acara kebaktian. Selain Katolik dan Protestan, ada juga beberapa komunitas agama lainnya, seperti penganut Hinduisme, Sikhisme, Judaisme, Baha'i dan Zoroastianisme.

\section{Siapakah Kaum Muslim Indonesia di Hong Kong?}

Sebagaimana telah disebut, komunitas Muslim sendiri merupakan kelompok minoritas dengan jumlah cukup signifikan di Hong Kong. Seperti tampak dalam Tabel 1, persentase kaum Muslim terhadap total penduduk Hong Kong terus meningkat dari tahun ke tahun. Dengan angka perkiraan sebesar 300.000 jiwa pada tahun 2014, persentase komunitas Muslim pada tahun itu mencapai sekitar 4,13 persen dari total 7.264.100 penduduk Hong Kong. Menurut Wai-Yip Ho, Islam menjadi salah satu dari 'enam agama besar' di Hong Kong, selain

${ }^{7}$ T Ibid., h. 334 - 339 
Konfusianisme, Buddhisme, Taoisme, kendati secara nasional Jawa Barat Katolik, dan Protestan. ${ }^{8}$ merupakan provinsi pemasok pekerja TABEL 1. PERSENTASE MUSLIM TERHADAP TOTAL POPULASI HONG KONG (1900 - 2014) TAHUN

Muslim $19001963 \quad 1971 \quad 19811991 \quad 1999 \quad 2009 \quad 2011 \quad 2012 \quad 2013 \quad 2014$

$\begin{array}{llllllllllll}\% & 0.3 & 0.14 & 0.25 & 0.6 & 0.8 & 1.1 & 3.14 & 3.11 & 3.35 & 4.16 & 4.13\end{array}$

Sumber: Angka untuk 1900-2012 diolah Wai-Yip Ho (2014) dari Hong Kong Year Book tahun terkait; angka untuk tahun 2013-2014, diolah peneliti dari Hong Kong Year Book tahun 2013 dan 2014.

Dari sekitar 300.000 penduduk Muslim itu, separuhnya merupakan kombinasi antara etnis China, terutama dari suku Hui, sekitar 40.000 jiwa; keturunan Pakistan, sekitar 30.000 jiwa; dan sisanya, berasal dari berbagai negara seperti India, Malaysia, negara-negara Timur Tengah dan Afrika'. Separuh lagi, atau sekitar 150.000 jiwa, adalah orang Indonesia. Dari jumlah tersebut, sekitar 99 persen adalah pekerja migran Indonesia, yang hampir seluruhnya wanita dan bekerja sebagai pembantu rumah tangga (domestic helpers). Sisanya adalah ekspatriat Indonesia, baik yang bekerja di sektor pemerintahan maupun swasta, serta menjadi pelajar dan mahasiswa.

Mayoritas pekerja migran Indonesia di Hong Kong berasal dari Provinsi Jawa Timur, disusul Provinsi Jawa Tengah, ${ }^{10}$

${ }^{8}$ Wai - Yip Ho. Loc. Cit, h. 205

9 HKSAR Government, Information Services Department. 2014. Hong Kong Year Book 2014. Hong Kong: Government Logistics Department

${ }^{10}$ Angka perkiraan mengenai jumlah dan daerah asal mayoritas pekerja migran Indoensia itu berasal dari keterangan beberapa petugas di KJRI Hong Kong (Wawancara dengan Yolvis, staf konsul Penerangan, Sosial dan Budaya, dan Teguh Subaryanto, staf bagian umum, KJRI Hong Kong; 18 Desember 2015). Namun, angka pasti jumlah itu masih menunggu keterangan dari Konsul Tenaga Kerja yang menjanjikan untuk memberikan data mengenai profil pekerja migran migran Indonesia terbanyak dari tahun ke tahun, disusul Jawa Tengah, Jawa Timur, dan Nusa Tenggara Barat. ${ }^{11}$ Peneliti belum memperoleh data pasti mengenai berapa lama rata-rata pekerja migran Indonesia bekerja di Hong Kong. Namun, berdasarkan wawancara dengan sejumlah pekerja migran yang peneliti sempat temui, mereka telah bekerja di Hong Kong berkisar antara 5-23 tahun. Setiap kontrak kerja berdurasi 2 tahun, dan dapat diperpanjang kembali. Sejak 1 Oktober 2015, pemerintah Hong Kong menetapkan besaran upah minimum bagi pembantu rumah tangga sebesar 4.210 dollar Hong Kong (HKD) atau sekitar Rp 7.578.000 (berdasarkan kurs HKD $1=\mathrm{Rp}$ 1.800 yang berlaku pada 16 Desember 2015). ${ }^{12}$ Angka itu telah naik sebesar HKD 890 dari upah minimum pembantu rumah tangga sepuluh tahun lalu, yang saat itu sebesar HKD 3.320 (per 19 Mei 2005). ${ }^{13}$

dari segi usia, asal daerah, dan lokasi penempatan. Namun, hingga tulisan ini dibuat, peneliti belum menerima data yang dijanjikan dari pihak KJRI Hong Kong.

${ }^{11}$ Badan Nasional Penempatan dan Perlindungan Tenaga Kerja Indonesia (BNP2TKI), "Penempatan dan Perlindungan Tenaga Kerja Indonesia Tahun 2013;" "Data Penempatan dan Perlindungan Tenaga Kerja Indonesia Tahun 2014;" dan "Data Penempatan Tenaga Kerja Indonesia Berdasarkan Negara Periode 1 Januari s.d. 31 Oktober 2015."

${ }^{12}$ Pusat Sumber Daya Buruh Migran, "Kewajibankewajiban Majikan dalam Menggaji BMI," tersedia di http://www.buruhmigran.or.id/2015/12/01/ kewajiban-kewajiban-majikan-dalam-menggaji-bmihong-kong/; diakses 25 Desember 2015.

${ }^{13}$ Asian Migrant Centre, Indonesian Migrant Workers Union, the Hong Kong Coalition of Indonesian Migrant Workers Organization, Underpayment 2: Pemerasan Sistematis Berkepanjangan pada Buruh Migran Indonesia di Hong Kong, Suatu Studi Mendalam (Asian 
Dengan demikian, profil mayoritas kaum Muslim Indonesia di Hong Kong berbeda dari kaum Muslim etnis lain, seperti Pakistan dan China. Jika komunitaskomunitas yang belakangan tersebut cukup banyak yang lahir di Hong Kong, menempati posisi sosial yang baik, dan karena itu memiliki daya tawar sosial yang lebih tinggi, mayoritas komunitas Muslim Indonesia adalah komunitas pendatang, bekerja sebagai pekerja migran pada sektor pembantu rumah tangga, dengan tingkat keterampilan yang secara umum rendah (unskilled labor). Hal ini mengakibatkan komunitas Muslim Indonesia memiliki daya tawar yang rendah dalam kehidupan sosial dan budaya masyarakat di Hong Kong. Karakteristik dan daya tawar sosial yang rendah yang dimiliki komunitas Muslim Indonesia di Hong Kong pada akhirnya juga memengaruhi bentuk dan corak aktivitas keagamaan dan layanan pendidikan agama dan keagamaan yang tersedia bagi kaum Muslim Indonesia di Hong Kong.

\section{Organisasi Islam di Hong Kong}

Sebelum membahas tentang pendidikan agama dan keagamaan kaum Muslim Indonesia di Hong Kong, penting terlebih dahulu melihat organisasi-organisasi keislaman yang memiliki peran penting dalam aktivitas keagamaan maupun penyediaan layanan pendidikan bagi komunitas Muslim di Hong Kong.

Migrant Centre, Indonesian Migrant Workers Union, the Hong Kong Coalition of Indonesian Migrant Workers Organization, September 2007): 7.

\section{Incorporated Trustees of the Islamic Community Fund of Hong Kong}

Salah satu organisasi keislaman yang diakui pemerintah Hong Kong menjadi semacam organisasi payung dari organisasiorganisasi Islam di Hong Kong adalah Incorporated Trustees of the Islamic Community Fund of Hong Kong. Pemerintah Hong Kong mengakui organisasi ini sebagai organisasi amal, dengan sertifikat pengakuan yang dikeluarkan pada 1 Desember 1970. Organisasi ini, yang dikenal di kalangan Muslim Hong Kong sebagai Dewan Wali Amanat (Board of Trustees, BOT), diakui pemerintah Hong Kong sebagai lembaga utama yang mewakili kepentingan kaum Muslim Hong Kong. ${ }^{14}$

BOT terdiri atas 7 orang anggota yang diusulkan oleh empat organisasi yang menjadi pendiri BOT, yaitu masing-masing 2 anggota mewakili Islamic Union of Hong Kong, Pakistan Association of Hong Kong, Anjumane Burhani Hong Kong Dawoodi Bohra Association, dan 1 anggota mewakili Indian Muslim Association of Hong Kong.

Pemerintah Hong Kong telah memberikan tanah kepada BOT untuk berdirinya 5 masjid dan 2 pemakaman muslim. Kelima masjid yang dikelola BOT adalah (1) Masjid Jamia di Shelley Street, Distrik Central \& Western, Hong Kong Island, (2) Masjid Ammar \& Osman Ramju Sadick Islamic Centre di Oi Kwan Road, Distrik Wanchai, Hong Kong Island, (3) Masjid Chai Wan di Cape Collinson, Distrik Eastern, Hong Kong Island, (4) Masjid \& Islamic Centre Kowloon di Nathan Road, Tsim Sha Tsui, Distrik Yau Tsim Mong, Kowloon, dan (5)

${ }^{14}$ Lihat http://www.islamictrusthk.org/ introduction; diakses 15 Desember 2015. 
Masjid Stanley di 53 Tung Tau Wan Road, Stanley, Distrik Southern, Hong Kong Island. Selain mengelola masjid, BOT juga mengelola dua pemakaman Muslim, di Happy Valley, Distrik Wan Chai dan di Cape Collinson, Chai Wan, Distrik Eastern, yang kedua distrik itu berada di daerah Hong Kong Island.

Selain mengelola masjid dan pemakaman, beberapa kewenangan lain yang diberikan pemerintah Hong Kong kepada BOT adalah: 1) Mengelola madrasah dan maktab di masjid-masjid yang telah disebutkan; 2) Mengatur urusan pemakaman orang-orang Muslim yang wafat $^{15}$; 3) Mengangkat imam, guru pengajar al-Qur'an, staf pemakaman dan staf kantor; 4)Mengumumkan tanggal dan hari perayaan hari besar Islam, seperti awal Ramadan dan Idul Fitri dan Idul Adha; 5) Membeli waktu siaran radio dan melakukan program sahur dan iftar selama Ramadan; 6) Melakukan pengawasan produk halal dan mengeluarkan sertifikat halal di Hong Kong dan sebagian wilayah China; 7) Melaksanakan dakwah kepada Muslim dan non-Muslim, serta melakukan berbagai aktivitas untuk kepentingan kaum Muslim Hong Kong dan dakwah Islam; 9) Meningkatkan pemahaman di kalangan pemuka agama lain dan menyelenggarakan pertemuan lintas iman; 10) Mengunjungi dan mendidik kaum Muslim yang sedang menjadi tahanan di penjara; dan 11) Mengatur ifthar setiap hari selama bulan Ramadan di Masjid Kowloon untuk sekitar 2.500 jamaah.

15 Untuk warga Indonesia, kematian dan pemakaman kaum Muslim diurus oleh KJRI Hong Kong. Wawancara dengan Teguh Subaryanto, staf KJRI Hong Kong, 20 Desember 2013.

\section{Islamic Union of Hong Kong}

Islamic Union of Hong Kong (IUHK) telah terbentuk sejak lebih dari 100 tahun lalu oleh kaum Muslim yang berasal dari wilayah Anak Benua atau yang belakangan disebut sebagai Asia Selatan (mencakup India, Pakistan, Bangladesh, Nepal, Bhutan, Srilanka, dan Maldives) serta kepulauan Melayu. Kaum Muslim datang ke wilayah itu dengan tujuan utama melakukan aktivitas perdagangan. Pada 1980, Anggaran Dasar organsiasi ini disesuaikan untuk memenuhi persyaratan sebagai sebuah badan hukum yang diakui pemerintah.

Berkat wakaf dari Osman Ramju Sadick, Pusat Keislaman (Islamic Center) pertama di Hong Kong dapat berdiri, yang kemudian dinamai dengan Osman Ramju Sadick Islamic Center. Berlokasi di No. 40, Oi Kwan Road, Wan Chai, di situ berdiri pula Masjid Ammar. Tanah untuk komplek masjid dan pusat keislaman itu berasal dari hibah pemerintah Hong Kong, yang diberikan atas nama BOT. Dengan perjanjian khusus antara BOT dan IUHK, pengelolaan seluruh bangunan komplek masjid dan pusat keislaman itu berada di bawah tanggung jawab IUHK. Jumlah anggota IUHK kini sekitar 700 orang, yang berasal dari berbagai bangsa, seperti Pakistan, Melayu, China dan Inggris. ${ }^{16}$

\section{Pakistan Association of Hong Kong}

Mayoritas Muslim dari wilayah Anak Benua Indo-Pakistan (yang saat ini menjadi wilayah Pakistan) datang ke Hong Kong sekitar tahun 1880 sebagai serdadu dalam Batalion Hong Kong Singapura Angkatan

${ }^{16}$ Lihat jauh tentang Islamic Union of Hong Kong, lihat http://www.iuhk.org/; diakses 15 Desember 2015. 
Darat Inggris. Selain itu, ada pula di antara mereka yang bertugas sebagai anggota kepolisian, pegawai pemerintah, bank, sekolah, perusahaan swasta, serta pedagang. Pada 1950 mereka membentuk Pakistan Muslim Society, dan biasa melakukan pertemuan di masjid lama Ho Man Tin.

Pada 1957 Komisi Perdagangan Pakistan membuka kantor di Hong Kong, dan Komisioner Senior pertama dari Komisi itu berperan penting dalam menyatukan masyarakat Pakistan. Lalu orang-orang Pakistan mendaftarkan diri mereka pada pemerintah Hong Kong pada 1960 sebagai Pakistan Association of Hong Kong. Perkumpulan ini mengajukan permohonan kepada pemerintah Hong Kong untuk mendapat tanah yang akan dibangun bangunan bagi perkumpulan ini, dan permohonan itu disetujui pemerintah Hong Kong yang menghibahkan kepada mereka tanah seluas 2.504 meter persegi.

Pada 1969 bangunan dapat diselesaikan. Sejak saat itu berbagai perbaikan dilakukan, dan tempat itu menjadi tempat penyelenggaraan berbagai aktivitas komunitas Pakistan, termasuk aktivitas keagamaan, seperti pelaksanaan salat tarawih selama bulan Ramadan. ${ }^{17}$

\section{Anjumane Burhani Hong Kong Dawoodi Bohra Association}

Asosiasi ini adalah salah satu pendiri dari Incorporated Trustees of the Islamic Community Fund of Hong Kong, atau yang lebih dikenal sebagai BOT (Board of Trustees). Anggota perkumpulan ini merupakan penganut Syiah

${ }^{17}$ Lebih jauh tentang perkumpulan ini, lihat http://www.pakassociation.com.hk; diakses 15 Desember 2015. aliran Ismailiyah. Pada pertengahan abad ke-19, komunitas Bohra datang ke wilayah pesisir China untuk melakukan aktivitas perdaganan, dan menetap di pemukiman tempat orang asing dizinkan menetap. Meski mayoritas komunitas Bohra tinggal di wilayah Asia Selatan, namun dalam perkembangan selanjutnya, pemukiman komunitas ini juga dapat ditemukan di wilayah Afrika Timur, Asia Tenggara, Amerika Utara dan Inggris.

Migrasi generasi muda komunitas muda ke wilayah Amerika Utara dan Inggris memperlihatkan indikasi peralihan bertahap komunitas Bohra dari komunitas pedagang menjadi komunitas profesi, seperti dokter, insinyur, pengacara, dan sebagainya. Berdasarkan data Konsulat Jenderal India di Hong Kong, organisasi ini terdaftar sebagai salah satu organisasi India, yang saat ini berada di bawah pimpunan Khuzema Esmail Bhai Saheb Zakiuddin, dengan lokasi kantor di wilayah Distrik Central, Hong Kong Island..$^{18}$

\section{Indian Muslim Association of Hong Kong}

Kaum Muslim India pada mulanya datang ke Hong Kong sebagai bagian dari Angkatan Darat Inggris pada saat pembentukan wilayah koloni itu pada abad ke-19. Kedatangan mereka tidak lama kemudian disusul oleh komunitas pedagang dari India. Untuk kepentingan Muslim India beribadah itulah pada mulanya dibangun masjid di Tsim Sha Sui dan Ho Man Tin, yang keduanya berlokasi di daerah Semenanjung Kowloon, serta masjid Stanley di daerah Hong Kong Island. Sementara itu, Masjid

\footnotetext{
${ }^{18}$ Tentang komunitas Dawoodi Bohra, lihat www. dawoodi-bohras.com/ diakses 15 Desember 2015.
} 
Jamia di Shelley Street dibangun oleh seorang pengusaha dan dermawan India dari Bombay (kini Mumbai), Haji Mohammed Eshaq, pada 1905.

Pemisahan Pakistan dari India pada 1947 membuat komunitas Muslim India berada dalam posisi sulit dan serba salah, dengan kehadiran komunitas baru Muslim, yaitu Muslim Pakistan. Namun, pada pertengahan 1950an, komunitas Muslim India bangkit kembali, seiring dengan kedatangan generasi pedagang Muslim dari Republik India, serta Indochina, Singapura, Malaya (kini Malaysia), Ceylon (Srilanka), Burma, dan daerah lainnya.

Setelah sekian lama tidak memiliki perkumpulan, akhirnya terbentuk Indian Muslim Association (Jamaath) Limited dan meraih status badan hukum di bawah Peraturan tentang Organisasi (Companies Ordinance) pada September 1979 sebagai organsiasi nirlaba. Sebagai pengakuan atas kontribusi komunitas Muslim India dalam perkembangan Islam di Hong Kong, organisasi ini pun diundang menjadi anggota dari Board of Trustees (BOT) Hong Kong.

\section{Chinese Muslim Cultural and Fraternal Association}

Chinese Muslim Cultural and Fraternal Association secara resmi berdiri pada 1922 (1929) ${ }^{19}$ di Wan Chai, Hong Kong Island dan merupakan organisasi utama yang merepresentasikan kaum Muslim China di Hong Kong (Hong Kong Year Book 2014: 337;

\footnotetext{
${ }^{19}$ Hong Kong Year Book 2014 mencatat organisasi ini berdiri pada 1922, sementara Wai-Yip Ho (2014) menyebut tahun 1929. Pada 1963 organisasi ini resmi tercatat sebagai badan hukum berbentuk organisasi amal (http://www.islam.org.hk/cmcfa).
}

Ho 2014: 423). Secara historis, kaum Muslim China di Hong Kong umumnya merupakan suku Hui yang bermigrasi ke Hong Kong dari berbagai wilayah di China daratan, seperti Guangdong, Zhaoqing, Shanghai, Beijing, Nanking, dan China barat laut. Mereka telah bermukim di Hong Kong jauh sebelum Perjanjian Nanking antara China dan Inggris tahun 1842 pada akhir Perang Opium Pertama. Sebagian besar suku Hui bermigrasi akibat penindasan politik dan kerusuhan sosial yang terjadi di China pada masa itu, yang dikenal sebagai Pemberontakan Panthay (1856-1873), suatu gerakan separatis etnis Hui Muslim, yang dipimpin Du Wenxiu melawan Kekaisaran Qing di Povinsi Yunan di barat daya China. Peristiwa itu berbuntut pada pembantaian suku Hui Muslim oleh suku Han China.

Akibat berbagai peristiwa politik yang terjadi di China daratan, banyak suku Hui Muslim yang bermigrasi ke Hong Kong dalam jumlah besar. Setelah hidup sebagai komunitas seiman di Hongkong, pada 1918 mereka mendirikan Muslim Centre, yang kemudian berkembang menjadi Chinese Muslim Cultural and Fraternal Association..$^{20}$

Pada era pasca penyerahan kembali Hong Kong oleh Inggris ke pemerintah RRC tahun 1997, perwakilan dari "enam agama besar" diberikan jatah kursi perwakilan mewakili subsektor agama di dalam Komite Pemilu yang secara keseluruhan beranggotakan 1.200 orang, yang bertugas memilih Kepala Eksekutif Pemerintahan Daerah Adminsitratif Khusus Hong Kong (Hong Kong SAR) pada 2012. 10 dari 60 kursi untuk

${ }^{20}$ Wai-Yip Ho. 2014. “British Raj to China's Hong Kong: The rise of madrasas for ethnic Muslim youth." Modern Asian Studies 48, 2: h. 422. 
wakil subsektor agama itu dialokasikan untuk Chinese Muslim Cultural and Fraternal Association, yang mengindikasikan pengakuan terhadap kaum Muslim sebagai bagian dari masa depan Hong Kong (Ho 2014: 405). Selain melakukan berbagai kegiatan amal dan keagamaan, organisasi ini juga mengelola satu sekolah menengah, dua sekolah dasar, dan dua taman kanak-kanak.

\section{Organisasi Islam Indonesia di Hong Kong}

Selain beberapa organisasi keislaman yang telah disebut di atas, di Hong Kong juga terdapat organisasi-organisasi keislaman yang dibentuk oleh komunitas Muslim Indonesia. Menurut informasi dari KJRI Hong Kong terdapat ratusan perkumpulan keagamaan yang dibentuk komunitas Muslim Indonesia yang umumnya adalah pekerja migran yang bekerja dalam sektor pembantu rumah tangga. ${ }^{21}$ Sekitar 55 organisasi keagamaan menghimpun diri dalam organisasi Persatuan Organisasi Muslim Indonesia Hong Kong (POSMIH).22

Selain itu, ada Nahdlatul Ulama, yang juga telah membentuk cabang di Hong Kong sejak dua tahun terakhir. Kegiatan utama dari PC NU Hong Kong adalah pelaksanaan pengajian dan berbagai aktivitas keagamaan lainnya melalui perkumpulan-perkumpulan yang dibentuk pekerja migran Indonesia. Karena belum memiliki sekretariat atau tempat yang memadai, berbagai aktivitas itu dilakukan di tempat-tempat terbuka,

\footnotetext{
21 Wawancara dengan Yolvis dan Teguh Subaryanto, staf KJRI Hong Kong, 20 Desember 2015.

${ }^{22}$ Penulis mendapat daftar organisasi yang tergabung dalam POSMIH dari H. Abdul Muhaemin Karim, pria kelahiran Cirebon, yang menjadi wakil Malaysia dalam Islamic Union of Hong Kong, 19 Desember 2015.
}

seperti taman. PC NU Hong Kong berencana menggelar konferensi cabang (konfercab) pada Januari $2016 .{ }^{23}$

Selain itu, ada pula Dompet Dhuafa cabang Hong Kong, yang hadir di Hong Kong sejak 2004 dan telah mendapat pengesahan sebagai organisasi sosial nirlaba dan organisasi keagamaan dari pemerintah Hong Kong dengan nama Dompet Dhuafa Association Ltd..$^{24}$ Rovi Octaviano Vustany, selaku General Manager Dompet Dhuafa Hong Kong (DDHK), menyebutkan bahwa DDHK memiliki banyak aktivitas keagamaan di Hong Kong. Selain sebagai lembaga penghimpun dan penyalur dana-dana keagamaan yang besumber dari zakat, infak dan sedekah kaum Muslim di Hong Kong, DDHK juga menyelenggarakan kegiatan bimbingan baca Al Quran melalui salah satu unit pelaksana program, yaitu Lembaga Pengembangan Tilawatil Quran (LPTQ).

Rovi mengaku DD memiliki sekitar 300 donatur rutin di Hong Kong, yang dalam waktu-waktu tertentu, seperti Ramadan, bisa mencapai 1.000 orang lebih. Dana yang berhasil dikumpulkan per bulan sekitar Rp 5 milyar, yang seluruhnya digunakan untuk membiayai berbagai aktivitas keagamaan di Hong Kong. Ada 5 program inti (core program) yang dijalankan DDHK, yaitu: (1) pendidikan dan ketrampilan, (2) pelayanan dan bantuan kesehatan, (3) program sosial kemanusiaan,

\footnotetext{
${ }^{23}$ Wawancara dengan Teguh Subaryanto dan Ghazali, staf KJRI Hong Kong, 20 Desember 2015.

${ }^{24}$ Pengesahan diberikan auditor Hong Kong dengan sertifikat no. 35688231-000-04-10-8. Lihat http://www.ddhongkong.org/profil; diakses 25 Desember 2015.
} 
(4) ekonomi kemandirian, serta (5) advokasi dan media. ${ }^{25}$

\section{Pendidikan Agama di Hong Kong}

Sebagaimana telah disebut pada bagian awal paper ini, penelitian ini lebih difokuskan untuk melihat fenomena pendidikan keagamaan non-formal di Hong Kong. Alasan utamanya ialah pekerja migran Indonesia merupakan segmen terbesar dari komunitas Muslim Indonesia di Hong Kong. Mereka yang hampir seluruhnya wanita bekerja sebagai pembantu rumah tangga di berbagai tempat di Hong Kong. Karena mereka tidak diperkenankan membawa keluarga atau menikah, maka mereka sendirilah yang menjadi konsumen utama dari layanan pendidikan keagamaan, yang umumnya dilakukan dalam bentuk non-formal. Kendati demikian, sebelum membahas lebih jauh tentang pendidikan keagamaan, perlu pula disajikan gambaran umum mengenai layanan pendidikan agama formal yang berkembang di Hong Kong.

Di Hong Kong terdapat 7 sekolah Islam yang dikelola oleh komunitas Muslim, yang umumnya berasal dari etnis China dan Pakistan. Lima dari 7 sekolah itu dikelola oleh Chinese Muslim Cultural and Fraternal Association, sedangkan dua sekolah lainnya dikelola masing-masing oleh United Muslims Association of Hong Kong (UMAH) dan Incorporated Trustees of the Islamic Community Fund of Hong Kong. Sekolah-sekolah itu menyedikan pelajaran agama Islam yang umumnya tidak disediakan oleh sekolah-

${ }^{25}$ Wawancara dengan Rovi Octaviano Vustany, General Manager Dompet Dhuafa Hong Kong, 22 Desember 2015. sekolah umum di Hong Kong. Berikut adalah daftar sekolah-sekolah tersebut:

Tabel 2.

Daftar Sekolah Yang Dikelola Kaum Muslim Hong Kong

\begin{tabular}{|c|c|c|c|c|}
\hline NO. & $\begin{array}{c}\text { NAMA } \\
\text { SEKOLAH }\end{array}$ & ALAMAT & $\begin{array}{l}\text { DISTRIK/ } \\
\text { REGION }\end{array}$ & $\begin{array}{c}\text { LEMBAGA } \\
\text { PENGELOLA }\end{array}$ \\
\hline 01 & $\begin{array}{l}\text { Islamic } \\
\text { Kasim Tuet } \\
\text { Memorial } \\
\text { College }\end{array}$ & $\begin{array}{l}22 \text { Tsui Wan } \\
\text { Street, Chai } \\
\text { Wan }\end{array}$ & $\begin{array}{l}\text { Eastern, } \\
\text { Hong Kong } \\
\text { Island }\end{array}$ & $\begin{array}{l}\text { The Chinese } \\
\text { Muslim Cultural } \\
\text { \& Fraternal } \\
\text { Association }\end{array}$ \\
\hline 02 & $\begin{array}{l}\text { Islamic } \\
\text { Primary } \\
\text { School }\end{array}$ & Yau Oi Estate & $\begin{array}{l}\text { Tuen } \\
\text { Mun, New } \\
\text { Territories }\end{array}$ & $\begin{array}{l}\text { The Chinese } \\
\text { Muslim Cultural } \\
\text { \& Fraternal } \\
\text { Association }\end{array}$ \\
\hline 03 & $\begin{array}{l}\text { Islamic } \\
\text { Dharwood } \\
\text { Pau Memorial } \\
\text { Primary } \\
\text { School } \\
\end{array}$ & $\begin{array}{l}\text { Tsz Lok Estate, } \\
\text { Tsz Wan Shan }\end{array}$ & $\begin{array}{l}\text { Wong } \\
\text { Tai Sin, } \\
\text { Kowloon }\end{array}$ & $\begin{array}{l}\text { The Chinese } \\
\text { Muslim Cultural } \\
\text { \& Fraternal } \\
\text { Association }\end{array}$ \\
\hline 04 & $\begin{array}{l}\text { Islamic Pok Oi } \\
\text { Kindergarten }\end{array}$ & $\begin{array}{l}\text { Cheung On } \\
\text { Estate, Tsing Yi }\end{array}$ & $\begin{array}{l}\text { Kwai } \\
\text { Tsing, New } \\
\text { Territories }\end{array}$ & $\begin{array}{l}\text { The Chinese } \\
\text { Muslim Cultural } \\
\text { \& Fraternal } \\
\text { Association }\end{array}$ \\
\hline 05 & $\begin{array}{l}\text { Islamic Abu } \\
\text { Bakar Chui } \\
\text { Memorial } \\
\text { Kindergarten }\end{array}$ & $\begin{array}{l}\text { G/F., King Hei } \\
\text { House, Yiu Hing } \\
\text { Road, Tung Hei } \\
\text { Court, Shau Kei } \\
\text { Wan, H.K. }\end{array}$ & $\begin{array}{l}\text { Eastern, } \\
\text { Hong Kong } \\
\text { Island }\end{array}$ & $\begin{array}{l}\text { The Chinese } \\
\text { Muslim Cultural } \\
\text { \& Fraternal } \\
\text { Association }\end{array}$ \\
\hline 06 & $\begin{array}{l}\text { UMAH Int'I } \\
\text { Primary } \\
\text { School }\end{array}$ & $\begin{array}{l}\text { Fung Chi Chuen } \\
\text { Village, Wang } \\
\text { Chau Po box 51, } \\
\text { Yuen Long, N.T. }\end{array}$ & $\begin{array}{l}\text { Yuen } \\
\text { Long, New } \\
\text { Territories }\end{array}$ & $\begin{array}{l}\text { United Muslims } \\
\text { Association of } \\
\text { Hong Kong }\end{array}$ \\
\hline 07 & $\begin{array}{l}\text { Muslim } \\
\text { Community } \\
\text { Kindergarten }\end{array}$ & $\begin{array}{l}\text { G/F, Islamic } \\
\text { Centre, } 40 \text { Oi } \\
\text { Kwan Road, } \\
\text { Wanchai, H.K. }\end{array}$ & $\begin{array}{l}\text { Wan Chai, } \\
\text { Hong Kong } \\
\text { Island }\end{array}$ & $\begin{array}{l}\text { Incorporated } \\
\text { Trustees of } \\
\text { the Islamic } \\
\text { Community } \\
\text { Fund of H.K }\end{array}$ \\
\hline
\end{tabular}

Sumber: Light of Islam (2010), 'Schools Organized by Muslims in Hong Kong,' daring. Tersedia di: <http://www.islamhk.com/ en/?p=13\&a=view\&r=55>, [diakses 16 Desember 2015].

Islamic Kasim Tuet Memorial College (IKTMC) merupakan salah satu sekolah favorit bagi kaum Muslim di Hong Kong, yang menyediakan layanan pendidikan tingkat menengah (setara SMP dan SMA). ${ }^{26}$ Sekolah ini didirikan pada 1970 oleh Chinese Muslim Cultural and Fraternal Association. Sekolah yang sebelumnya dikenal sebagai Islamic English School ini didirikan untuk

${ }^{26}$ Beberapa pejabat KJRI juga menyekolahkan anaknya di sini. 
menyediakan layanan pendidikan bagi generasi kedua kaum Muslim yang lahir di Hong Kong. Meski awalnya didominasi siswa dari kalangan Muslim China, namun belakangan jumlah siswa etnis China turun menjadi sekitar 60 persen, dan sisanya terdiri siswa yang berasal dari keturunan bangsa-bangsa lain, seperti Pakistan, Filipina, Indonesia, Nepal, India, Australia, dan Brunei. ${ }^{27}$

IKTCM mengusung visi sebagai berikut: Inspired by the principles in the Holy Quran and teachings of Prophet Muhammad (May Peace Be Upon Him), our college aims at providing holistic education to individuals that ensures love of peace and kindness to mankind and other creatures; true success in this life and in the life hereafter. We endeavour to provide quality education through well-balanced curriculum in moral, academic, physical, social, civic, aesthetic and spiritual domains.

Adapun misi yang dinyatakan untuk mewujudkan visi tersebut adalah: 1) To explain and demonstrate how Islam is a complete way of life; 2) To provide and maintain a harmonious environment in which students from multicultural background can learn and work together in an enjoyable and successful way; 3) To nurture in students a sense of belonging to the school and the society in order to function effectively as civic-minded and responsible citizens of Hong Kong; 4) To provide each student with opportunities to exhibit individual talents and enjoy ever increasing self-esteem; 5) To arouse students' interest towards learning and stimulate critical thinking in order to equip them

${ }^{27}$ John Nguyet Erni dan Lisa Yuk-ming Leung. 2014. Understanding South Asian Minorities in Hong Kong. Hong Kong: Hong Kong University Press, h. 27 with problem solving and decision making skills; 6) To incorporate all internal and community resources as well as information technology in all aspects of the curriculum; 7) To foster cooperation among students, parents, teachers, school management and the community; 8) To cultivate in students a true love for lifelong learning.

Mata pelajaran inti (core subjects) mencakup bahasa China, bahasa Inggris, matematika dan liberal studies. Mata pelajaran lain meliputi musik, pendidikan jasmani, studi Islam, dan seni visual (visual arts). Adapun mata pelajaran pilihan mencakup fisika; biologi; bisnis, akuntasi, dan keuangan; etika dan studi agama; kimia; teknologi komunikasi dan informasi; sejarah; sains terpadu; dan ekonomi. Selain itu, IKTMC juga menyediakan waktu untuk pelajaran membaca al-Qur'an, di samping juga membuka kelas untuk bahasa Urdu dan bahasa Arab. ${ }^{28}$

Seperti telah disebut disebelumnya, layanan pendidikan agama formal yang disediakan melalui sekolah-sekolah yang diorganisasi komunitas Muslim di Hong Kong memang penting bagi generasi Muslim yang lahir dan tumbuh di sana, namun tidak memiliki arti penting bagi komunitas Muslim Indonesia yang berasal dari kalangan pekerja migran dalam sektor pembantu rumah tangga. Segmen ini datang ke Hong Kong hanya sebagai penduduk tidak tetap, yang juga tidak diperkenankan membawa anak dan keluarga, sehingga mereka tidak memiliki kebutuhan akan layanan pendidikan agama

\footnotetext{
${ }^{28}$ Untuk informasi lebih lanjut mengenai sekolah ini, lihat http://www.iktmc.edu.hk/; diakses 22 Desember 2015.
} 
formal. Sebaliknya, pendidikan keagamaan non-formal menjadi layanan yang sangat dibutuhkan bagi komunitas pekerja migran Muslim Indonesia.

\section{Pendidikan Keagamaan}

Pekerja migran Muslim Indonesia membentuk porsi terbesar dari populasi komunitas Muslim di Hong Kong dewasa ini. Namun, seperti ditulis Wai-Yip Ho, “... although Indonesian Muslim domestic helpers are large in number, they are politically weak, of low socio-economic status, and socially marginalized..."29. Besar dalam jumlah, tetapi kecil dalam nilai politik, sosial maupun ekonomi; itulah gambaran komunitas Muslim Indonesia di Hong Kong pada umumnya. Bandingkan dengan suku Hui Muslim, yang berjumlah sekitar 15 persen dari total jumlah komunitas Muslim Hong Kong, namun memiliki jatah 10 kursi dalam Komite Pemilu, yang memiliki hak pilih untuk memilih Kepala Eksekutif Pemerintah Daerah Adminstrasi Khusus Hong Kong.

Lemahnya posisi kaum Muslim Indonesia juga tercermin dari absennya mereka dalam berbagai organisasi Islam Hong Kong yang memiliki legitimasi kuat, seperti Incorporated Trustees of the Islamic Community Fund of Hong Kong atau Islamic Union of Hong Kong, yang telah disebut sebelumnya. Di antara berbagai sekolah Islam yang ada di Hong Kong, tidak satu pun ada sekolah yang dikelola Muslim Indonesia. Demikian pula dari sekitar 29 masjid dan/atau madrasah yang ada di Hong Kong seperti disajikan dalam Tabel 3

${ }^{29}$ Wai-Yip Ho. 2014. “British Raj to China's Hong Kong: The rise of madrasas for ethnic Muslim youth." Modern Asian Studies 48, 2, h. 428 di bawah, tidak satu pun yang dikelola oleh komunitas Muslim Indonesia.

Tabel 3.

Daftar Masjid/Madrasah Di Hong Kong

\begin{tabular}{|c|c|c|c|}
\hline No. & $\begin{array}{l}\text { NAMA MASJID/ } \\
\text { MADRASAH }\end{array}$ & DISTRIK & LEMBAGA SPONSOR \\
\hline 01 & $\begin{array}{l}\text { Kowloon Masjid } \\
\text { (Mosque) and } \\
\text { Islamic Centre }\end{array}$ & $\begin{array}{l}\text { Yau Tsim } \\
\text { Mong }\end{array}$ & $\begin{array}{l}\text { Incorporated Trustees of } \\
\text { the Islamic Community } \\
\text { Fund of H.K }\end{array}$ \\
\hline 02 & $\begin{array}{l}\text { Masjid Ammar } \\
\text { \&Osman Ramju } \\
\text { Sadick Islamic Centre }\end{array}$ & Wan Chai & $\begin{array}{l}\text { Incorporated Trustees of } \\
\text { the Islamic Community } \\
\text { Fund of H.K }\end{array}$ \\
\hline 03 & $\begin{array}{l}\text { Cape Collinson } \\
\text { Chai Wan Masjid } \\
\text { (Mosque) }\end{array}$ & Eastern & $\begin{array}{l}\text { Incorporated Trustees of } \\
\text { the Islamic Community } \\
\text { Fund of H.K }\end{array}$ \\
\hline 04 & $\begin{array}{l}\text { Stanley Masjid } \\
\text { (Mosque) }\end{array}$ & Southern & $\begin{array}{l}\text { Incorporated Trustees of } \\
\text { the Islamic Community } \\
\text { Fund of H.K }\end{array}$ \\
\hline 05 & $\begin{array}{l}\text { Jamia Masjid / Shelly } \\
\text { Street Mosque }\end{array}$ & $\begin{array}{l}\text { Central and } \\
\text { Western }\end{array}$ & $\begin{array}{l}\text { Incorporated Trustees of } \\
\text { the Islamic Community } \\
\text { Fund of H.K }\end{array}$ \\
\hline 06 & $\begin{array}{l}\text { Sham Shui Po KNM } \\
\text { Islamic Education } \\
\text { Center }\end{array}$ & Sham Shui Po & $\begin{array}{l}\text { Khatme- Nubuwwat } \\
\text { Movement (KNM) Hong } \\
\text { Kong }\end{array}$ \\
\hline 07 & $\begin{array}{l}\text { Kwun Tong KNM } \\
\text { Islamic Education } \\
\text { Center }\end{array}$ & Kwun Tong & $\begin{array}{l}\text { Khatme-Nubuwwat } \\
\text { Movement (KNM) Hong } \\
\text { Kong }\end{array}$ \\
\hline 08 & Tseung Kwan 0 & Sai Kung & $\begin{array}{l}\text { Khatme- Nubuwwat } \\
\text { Movement (KNM) Hong } \\
\text { Kong }\end{array}$ \\
\hline 09 & $\begin{array}{l}\text { Kwai Chung KNM } \\
\text { Islamic Education } \\
\text { Center }\end{array}$ & Kwai Tsing & $\begin{array}{l}\text { Khatme-Nubuwwat } \\
\text { Movement (KNM) Hong } \\
\text { Kong }\end{array}$ \\
\hline 10 & $\begin{array}{l}\text { Tuen Mun KNM } \\
\text { Islamic Education } \\
\text { Center }\end{array}$ & Tuen Mun & $\begin{array}{l}\text { Khatme-Nubuwwat } \\
\text { Movement (KNM) } \\
\text { HongKong }\end{array}$ \\
\hline 11 & $\begin{array}{l}\text { Kam Tin KNM Islamic } \\
\text { Education Centre }\end{array}$ & Yuen Long & $\begin{array}{l}\text { Khatme-Nubuwwat } \\
\text { Movement (KNM) Hong } \\
\text { Kong }\end{array}$ \\
\hline 12 & $\begin{array}{l}\text { Tai Wai KNM Islamic } \\
\text { Education Centre }\end{array}$ & Shatin & $\begin{array}{l}\text { Khatme-Nubuwwat } \\
\text { Movement (KNM) Hong } \\
\text { Kong }\end{array}$ \\
\hline 13 & $\begin{array}{l}\text { Madrasah-Tul- } \\
\text { Madinah }\end{array}$ & Kowloon City & Dawat-e- Islami,H.K. \\
\hline 14 & $\begin{array}{l}\text { Madrasah Faizan- } \\
\text { e-Madinah (Tsuen } \\
\text { Wan) }\end{array}$ & Tsuen Wan & Dawat-e- Islami,H.K. \\
\hline 15 & $\begin{array}{l}\text { Madrasah Kanzul- } \\
\text { Eman }\end{array}$ & Tuen Mun & Dawat-e- Islami,H.K. \\
\hline 16 & $\begin{array}{l}\text { Madrasah Fazian-e- } \\
\text { Aulia (Ping Shan) }\end{array}$ & Yuen Long & Dawat-e- Islami,H.K. \\
\hline 17 & Yaumatei Madrasah & $\begin{array}{l}\text { Yau Tsim } \\
\text { Mong }\end{array}$ & $\begin{array}{l}\text { United Welfare Union Lto } \\
\text { (H.K) }\end{array}$ \\
\hline
\end{tabular}




\begin{tabular}{|c|c|c|c|}
\hline 18 & $\begin{array}{l}\text { To Kwa Wan } \\
\text { Madrasah }\end{array}$ & Kowloon City & $\begin{array}{l}\text { United Welfare Union Ltd } \\
\text { (H.K) }\end{array}$ \\
\hline 19 & $\begin{array}{l}\text { Tung Chung } \\
\text { Madrassah }\end{array}$ & Islands & $\begin{array}{l}\text { United Welfare Union } \\
\text { Ltd (H.K) }\end{array}$ \\
\hline 20 & $\begin{array}{l}\text { Minhajul Quran } \\
\text { Madrasah (San Po } \\
\text { Kong) }\end{array}$ & Wong Tai Sin & Idara Minhaj- Ul-Quran \\
\hline 21 & $\begin{array}{l}\text { Minhajul Quran } \\
\text { Madrasah (Kwai } \\
\text { Chung) }\end{array}$ & Kwai Tsing & Idara Minhaj- UI-Quran \\
\hline 22 & $\begin{array}{l}\text { Islamic Centre for } \\
\text { Community Service }\end{array}$ & Yuen Long & $\begin{array}{l}\text { Pakistan Islamic Welfare } \\
\text { Union Incorporated Ltd } \\
\text { (HK) }\end{array}$ \\
\hline 23 & $\begin{array}{l}\text { Madrasah } \\
\text { Muhammadia } \\
\text { Ghosia }\end{array}$ & Yuen Long & $\begin{array}{l}\text { Pakistan Islamic Welfare } \\
\text { Union Incorporated Ltd } \\
\text { (HK) }\end{array}$ \\
\hline 24 & $\begin{array}{l}\text { United Muslim } \\
\text { Association Tuen } \\
\text { Mun }\end{array}$ & Tuen Mun & $\begin{array}{l}\text { United Muslim Association } \\
\text { of H.K. }\end{array}$ \\
\hline 25 & $\begin{array}{l}\text { Al-Sufah Madrasah } \\
\text { (H.K.) }\end{array}$ & Kwai Tsing & Nil \\
\hline 26 & $\begin{array}{l}\text { Faiz-UI-Quran } \\
\text { Madrasah (Tsuen } \\
\text { Wan) }\end{array}$ & Tsuen Wan & Iqraa Foundation HK \\
\hline 27 & Kam Tin Madrasah & Yuen Long & $\begin{array}{l}\text { Pakistan Traders } \\
\text { Association HK }\end{array}$ \\
\hline 28 & $\begin{array}{l}\text { Prayer Room of City } \\
\text { University }\end{array}$ & Kowloon City & Nil \\
\hline 29 & Madrasah-tul- Hira & Sham Shui Po & Hazrat Sultan Bahu Society \\
\hline
\end{tabular}

Sumber: Light of Islam (2010), 'Schools Organized by Muslims in Hong Kong,' daring. Tersedia di: 〈http://www.islamhk.com/en/?p=13\&a=view\&r=55>, [diakses 16 Desember 2015].

Lalu bagaimana pekerja migran Muslim Indonesia memenuhi kebutuhan mereka akan layanan pendidikan keagamaan?. Pertama-tama mereka menghimpun diri dalam berbagai organisasi atau perkumpulan keagamaan, seperti majelis taklim di Indonesia. "Mereka membentuk organisasi sendiri, menentukan pengurus mereka sendiri, dan juga menyelenggarakan aktivitas pengajian sendiri. Jadi benar-benar seperti organisasi dari mereka, oleh mereka, dan untuk mereka," ungkap Yolvis, salah seorang staf di KJRI Hong Kong. ${ }^{30}$ Yolvis juga

${ }^{30}$ Wawancara dengan Yolvis, staf konsul Pensosbud, KJRI Hong Kong, 18 Desember 2015. menyebut bahwa dari segi jumlah, organisasi keagamaan yang dibentuk pekerja migran Indonesia dapat mencapai ratusan. Namun, baru sebanyak 55 organisasi yang bergabung dalam wadah Persatuan Organisasi Muslim Indonesia Hong Kong (POSMIH).

Selanjutnya mereka menyelenggarkan aktivitas pendidikan keagamaan, yang dapat dibagi ke dalam dua bentuk: reguler dan non-reguler. Aktivitas yang bersifat reguler adalah penyelengaraan pendidikan keagamaan, berupa pengajian, setiap hari Minggu, hari umumnya pekerja migran mengambil hak liburnya dalam seminggu. Aktivitas non-reguler berupa penyelenggaraan kegiatan pengajian, dengan mengundang berbagai tokoh agama atau penceramah, umumnya penceramah kondang yang berasal dari Indonesia.

Aktivitas pengajian reguler umumnya diadakan dengan memanfaatkan flat apartemen, masjid dan pusat keislaman yang ada, dan juga mushalla di KJRI Hong Kong. H. Abdul Muhaemin, Da'wah Executive pada Islamic Union of Hong Kong, mengemukakan bahwa lantai 3 di komplek Masjid Ammar \& Osman Ramju Sadick Islamic Centre setiap Sabtu digunakan oleh pekerja migran untuk mengadakan aktivitas pengajian. Komplek itu sendiri buka setiap hari, dan untuk hari-hari selain Sabtu, tempat itu biasanya digunakan komunitas Muslim dari berbagai bangsa, termasuk komunitas Indonesia nonpekerja pembantu rumah tangga. Mengenai buku-buku pegangan, Muhaemin menjelaskan:

Untuk belajar membaca Al Quran, kitab pegangan yang biasa digunakan adalah Iqra 6 jilid dengan penyusun As'ad Humam. Adapun kitab yang biasa digunakan untuk 
materi tafsir adalah Al Munir [fi al-'Aqidah wa al-Syari'ah wa al-Manhaj] karya Wahbah Al-Zuhayli dan Tafsir Al Azhar karya Hamka. Fiqh Sunnah karya Sayyid Sabiq digunakan untuk materi fikih, sementara untuk pelajaran Tauhid, digunakan kurikulum dari Malaysia. ${ }^{31}$

Mushalla Al Falah, yang terdapat di KJRI Hong Kong juga kerap digunakan untuk aktivitas pengajian pekerja migran ketika mereka libur, terutama hari Sabtu dan Minggu. Selain itu, pekerja migran juga menggunakan fasilitas publik, berupa taman, untuk aktivitas mereka. ${ }^{32}$

Fasilitas publik yang favorit digunakan pekerja migran Indonesia untuk menyelenggarakan aktivitas pendidikan keagamaan non-formal, dan sebenarnya juga aktivitas nonkeagamaan lainnya, adalah Taman Victoria (Victoria Park), yang terletak di daerah Causeway Bay, Distrik Eastern, Hong Kong Island. ${ }^{33}$ Berdasarkan observasi peneliti, pada hari Minggu taman itu dihadiri oleh ribuan pengunjung dengan

${ }^{31}$ Wawancara dengan H. Abdul Muhaemin Karim, Da'wah Executive pada Islamic Union of Hong Kong, 19 Desember 2015.

${ }^{32}$ Wawancara dengan Yolvis, staf pada konsul Pensosbud KJRI Hong Kong, 18 Desember 2015; Teguh Subaryanto, staf KJRI Hong Kong, 19 Desember 2015; dan Rafael Walangitan, kepala rumah tangga KJRI Hong Kong, 22 Desember 2015. Rafael juga berperan sebagai Ketua Pengurus Mushalla KJRI Hong Kong.

${ }^{3}$ Popularitas tempat ini bagi pekerja migran Indonesia juga disebut dalam Connor (2014), yang bahkan diduga membentuk imajinasi umum warga Hong Kong tentang kaum Muslim Indonesia. Seperti dilaporkan BBC, pada salat Idul Fitri tahun ini (8 Juli 2015), ada sekitar 50.000 pekerja migranyang memadai Taman Victoria untuk menghadiri pelaksanaan salat Idul Fitri. (Lihat "Salat Ied, puluhan ribu WNI di Hong Kong padati Victoria Park," http://www.bbc. com/indonesia/berita_indonesia/2015/07/150718_ indonesia_hongkong_muslim; diakses 25 Desember 2015. beragam kepentingan yang berbeda. Ada yang sekadar bersantai untuk melepas diri sejenak dari rutinitas kehidupan di Hong Kong. Ada yang berolahraga. Ada yang menggelar acara dengan mengundang pembicara terkait motivasi. Ada pula, seperti yang menjadi fokus penelitian ini, komunitas yang memanfaatkan taman ini untuk menggelar aktivitas pendidikan

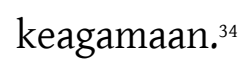

Salah satu aktivitas pendidikan keagamaan yang sempat peneliti observasi adalah pendidikan baca Al Quran yang difasilitasi oleh tutor dari Lembaga Pengembangan Tilawatil Quran (LPTQ) Dompet Dhuafa. Berdasarkan pengamatan, ada sekitar 3 kelompok, dengan masingmasing kelompok terdiri atas 10-12 peserta, yang sedang melakukan aktivitas membaca Al Quran di bawah tenda putih yang tersedia di taman.

Rikna Dewi, yang menjadi koordinator LPTQ itu, juga adalah pekerja migran yang berprofesi sebagai pembantu rumah tangga. Ia adalah lulusan Madrasah Aliyah Negeri (MAN), dan pernah mendapat pelatihan sebelumnya untuk bimbingan baca $\mathrm{Al}$ Quran dari Taman Pendidikan Al Quran An Nahdliyah Tulungagung Jawa Timur. Utusan dari An Nahdliyah Tulungagung, antara lain H. Sabaruddin, pernah diundang ke Hong Kong untuk memberi pelatihan metode ini kepada sejumlah orang, yang kemudian menjadi tutor bagi pekerja migran lainnya di Hong Kong. Metode inilah yang digunakan Rikna untuk membimbing pekerja migran

${ }^{34}$ Observasi dilakukan pada Minggu, 20 Desember 2015, mulai pukul 11.00 waktu setempat. 
Indonesia lainnya untuk belajar membaca Quran. ${ }^{35}$

Metode An-Nahdiyah adalah metode belajar membaca Al Quran, atau huruf hijaiyah, dengan diiringi irama ketukan. Dengan menggunakan irama ketukan itu, metode itu diyakini dapat lebih membantu peserta dalam belajar membaca Al Quran. Buku pegangan yang digunakan berjudul Cepat Tanggap Belajar Al Quran (yang disusun dan dicetak oleh LP Ma'arif NU Cabang Tulungagung), dan dilengkapi dengan buku Pedoman Pengelolaan Taman Pendidikan Al Quran: Metode Cepat Tanggap Belajar Al Quran An Nahdliyah (disusun oleh Pimpinan Pusat Majelis Pembina Taman Pendidikan Al Quran An Nahdliyah Tulungagung). Buku lain yang digunakan antara lain Pelajaran Tajwid karangan Abdullah Asy'ari, BA (Surabaya: Penerbit Apollo Lestari). Lalu ada buku berjudul Alala, buku tentang akhlak terbitan Pesantren Lirboyo, Kediri, Jawa Timur; serta buku terjemah bahasa Jawa dari Al Mabadi al Fiqhiyah 'ala Mazahib al Imam al Syafii karangan 'Umar Abd al-Jabbar (penerjemah Sibth Musthafa Muhammad bin Ahmad).

Selain Rikna, ada sekitar 14 tutor lain yang difasilitasi LPTQ Dompet Dhuafa Hong Kong. Namun, Dompet Dhuafa Hong Kong hanya memfasilitasi kelompok pengajian itu dengan pengeras suara dan alas berupa spanduk bekas yang digunakan kelompokkelompok pengajian di Taman Victoria, dan juga tempat-tempat lainnya. Rikna sendiri mengaku tidak mendapat honor atau insentif dari Dompet Dhuafa untuk aktivitas tutorialnya itu. "Yah, sumber dana Dompet Dhuafa 'kan dari zakat, infak dan sedakah....

${ }^{35}$ Wawancara dengan Rikna Dewi, koordinator LPTQ Dompet Dhuafa Hong Kong, 20 Desember 2015. saya sendiri menjalankan aktivitas ini lillahi ta'ala," ujar Rikna. ${ }^{36}$

Selain aktivitas pengajian reguler, seperti telah disebut, organisasiorganisasi keislaman Indonesia juga mengadakan aktivitas pengajian nonreguler, biasanya berupa acara pengajian dengan mendatangkan narasumber atau penceramah dari Indonesia. Beberapa penceramah kondang yang pernah diundang komunitas Muslim Indonesia di Hong Kong adalah Arifin Ilham, Yusuf Mansur, Maulana, dan Sholeh Mahmoed Nasution, yang dikenal dengan panggilan "Solmed". ${ }^{37}$ Aktivitas itu umumnya dilakukan dengan menyewa tempat di aula, atau tempat tertutup di taman, dan mengenakan tiket bayaran untuk peserta yang hendak hadir. Harga tiket yang dikemas dalam bentuk "infak" itu sekitar HKD 50 atau setara dengan Rp 90.000 (dalam kurs HKD 1 = Rp 1.800). Selain itu, para penyelenggara juga melakukan pengumpulan dana dengan mencari donasi dari perusahaan-perusahaan Indonesia

\footnotetext{
${ }^{36}$ Wawancara dengan Rikna Dewi, koordinator LPTQ Dompet Dhuafa Hong Kong, 20 Desember 2015.

${ }^{37}$ Terkait "Solmed", di Taman Victoria secara kebetulan peneliti bertemu dengan penyelenggara acara yang menghadirkan "Solmed" sebagai penceramah. Pada kesempatan itu, ia mengklarifikasi sejumlah informasi yang berkembang terkait kontroversi kedatangan "Solmed" di Hong Kong. Wawancara dengan Tri Puji, koordinator Jami'atu Sakinah di Tsim Sha Tsui, Kowloon, 20 Desember 2015. Arifin diketahui pernah berceramah di Hong Kong pada 23 Maret 2014 di Lai Chi Kok, kawasan Semenanjung Kowloon (lihat videonya di YouTube, www.youtube.com/watch? $=\mathrm{dmxu} 5$ cylmQs). Sementara itu, Maulana tercatat pernah datang untuk berceramah di Hong Kong pada 8 Juni 2014 (lihat videonya di YouTube, https://www.youtube. com/watch?v=g-E66gjhkxo dan https://www. youtube.com/watch?v=07eQw93vmLY).
} 
di Hong Kong, KJRI Hong Kong, dan para donator lainnya.

Beberapa pekerja migran sendiri mengaku aktivitas mendatangkan penceramah dari Indonesia, dengan segala biaya yang harus ditanggung, tidak lain mencerminkan kebutuhan luar biasa para pekerja migran Indonesia akan siraman rohani atau nasihat keagamaan dari tokoh-tokoh agama. "Kami sungguh sangat berharap agar Kementerian Agama dapat memfasilitasi kedatangan tokohtokoh agama untuk memenuhi kebutuhan pekerja migran Hong Kong akan pembinaan keagamaan," ungkap Nining Haryani, salah seorang pekerja migran yang tergabung dalam PC NU Hong Kong. ${ }^{38}$ Peneliti sendiri menyaksikan bahwa atmosfer kebebasan di Hong Kong yang sangat luar biasa telah menimbulkan berbagai dampak luar biasa, antara lain terjadinya perubahan perilaku seksual pada sebagian pekerja migran Indonesia. ${ }^{39}$

Kebutuhan pekerja migran yang tinggi akan kehadiran tokoh agama atau pembimbing agama, sementara kesulitan jarak, waktu, tenaga dan biaya yang mereka miliki, menyebabkan terbukanya celahcelah yang dimanfaatkan oleh oknumoknum tertentu untuk mencari keuntungan atas nama aktivitas dakwah atau keagamaan

\footnotetext{
${ }^{38}$ Wawancara dengan Nining Haryani, pekerja migran yang tergabung dalam organisasi Persatuan Islam Indonesia, disertai Mursingah, koordinator Majelis Taklim Roudhotul Jannah di Tsuen Wen, yang keduanya termasuk dalam jaringan anggota NU cabang Hong Kong, 20 Desember 2015.

${ }^{39}$ Ketika melakukan observasi di Taman Victoria, peneliti menyaksikan sejumlah pasangan lesbian berjalan secara bebas dengan menggendong boneka yang mereka perankan sebagai anak mereka; 20 Februari 2015.
}

lainnya. Seperti dikemukakan sejumlah informan, ada beberapa orang yang datang dari Indonesia, mengaku sebagai lulusan Pesantren Gontor, lalu menawarkan diri untuk menjadi penceramah, namun setelah dicek, ternyata yang bersangkutan bukan lulusan Gontor, bahkan juga bukan ustad atau penceramah agama. ${ }^{40}$ Kontroversi yang sempat ditimbulkan oleh "Solmed" di Hong Kong juga merupakan bagian dari ketimpangan antara sisi suplai dan sisi kebutuhan akan pembinaan keagamaan bagi pekerja migran Muslim Indonesia di Hong Kong. ${ }^{41}$

Selain itu, kondisi ini juga rentan dimanfaatkan oleh kelompok-kelompok tertentu yang ingin menyebarkan pemahaman keagamaan yang dinilai bertentangan dengan pemahaman yang dianut komunitas Muslim Indonesia di Hong Kong. "Ada organisasi yang mengundang ustad-ustad yang gemar untuk mencemooh kelompok lain telah melakukan bid'ah," kata Mursingah. ${ }^{42}$ Terkait dengan ini, dua orang penceramah sekaligus praktisi pengobatan ala nabi, Sahal Khan dan Perdana Ahmad, sempat dicekal masuk ke Hong Kong. Ini disebabkan dalam selebaran

${ }^{40}$ Wawancara kelompok dengan sejumlah pekerja migran di Taman Victoria, Causeway Bay, Hong Kong Island, 20 Desember 2015.

${ }^{41}$ Tentang kontroversi di Hong Kong yang terjadi akibat ulah penceramah Solmed pada Agustus 2013, lihat antara lain http://showbiz.liputan6.com/ $\mathrm{read} / 663404 /$ dituduh-menaikkan-tarif-dakwah-dihongkong-ustad-solmed-mengelak; dan http://www. kaskus.co.id/thread/5210fea5fdca17ab5e000004/ surat-terbuka-bmi-hongkong-untuk-ustadzsolmed/; diakses 20 Desember 2015.

${ }^{42}$ Wawancara dengan Mursingah, koordinator Majelis Taklim Roudhotul Jannah di Tsuen Wen, yang keduanya termasuk dalam jaringan anggota NU cabang Hong Kong, 20 Desember 2015. 
undangan untuk acara yang akan mereka datangi tercantum logo yang dikenal memiliki asosiasi dengan kelompok ISIS (Islamic State in Iraq and Syria). Acara yang sedianya digelar pada Minggu 22 Maret 2015 itu akhirnya dibatalkan, karena setibanya mereka di bandara internasional Hong Kong, kedua penceramah itu diinterogasi otoritas Hong Kong, lalu langsung dipulangkan ke Indonesia lewat Malaysia. ${ }^{43}$

Terkait dengan hal ini, Danur Lientara, Konsul Polisi di KJRI Hong Kong, mengemukakan bahwa menurutnya ada dua persoalan yang perlu dicermati. Pertama, dari sisi organisasi keagamaan itu sendiri, ada kecenderungan bahwa organisasi-organisasi itu terlihat lebih menonjol peran mereka sebagai event organizer yang memiliki motif meraih keuntungan dari penyelenggaraan acara-acara ceramah keagamaaan yang mengundang para pembicara kondang dari Indonesia itu. Seperti telah disebut, dengan kemasan dana "infak", para penyelenggara menjual tiket kepada calon peserta yang hendak menghadiri acara-acara keagamaan itu, dengan tarif berkisar antara HKD 50 hingga HKD 60 (setara Rp 90.000 hingga $\mathrm{Rp}$ 100.000) per tiket. Menurut Danur, sesungguhnya aktivitas memungut dana publik itu, termasuk dana keagamaan, tidak diperkenankan menurut aturan hukum di Hong Kong, kecuali bagi organisasi-

${ }^{43} \mathrm{http}: / / \mathrm{w} w \mathrm{w} . \mathrm{cnnindonesia.com} \mathrm{/}$ internasional/20150325142136-106-41747/dicekaldi-hong-kong-wni-bantah-terlibat-isis/.

Al Mujahidah Hong Kong, yang menjadi penyelenggara acara ini, telah membantah keterkaitan mereka dengan kelompok ISIS. Mereka berpandangan kalimat tauhid yang biasa digunakan dalam logo ISIS adalah kalimat universal bagi umat Islam; siapapun orang Islam dapat menggunakannya. organisasi yang telah memiliki status badan hukum sebagai organisasi amal. ${ }^{44}$

Persoalan kedua adalah terkait dengan para penceramah yang diundang oleh organisasi keislaman di Hong Kong. Karena mereka menyelenggarakan acara itu secara independen, dan tidak selalu melaporkannya kepada pihak KJRI, maka tidak seluruh aktivitas keagamaan yang melibatkan para penceramah dan pendakwah dari Indonesia itu dapat dipantau. Termasuk aktivitas-aktivitas sejumlah oknum yang melakukan penipuan atas nama dakwah agama. Danur memperlihatkan sebuah surat yang berisi pengaduan dari seorang pekerja migran mengenai aktivitas penipuan yang dilakukan seseorang yang mengaku sebagai ustad atau tokoh agama. ${ }^{45}$ Belum lagi soal pandangan atau pemahaman keagamaan yang disebarkan oleh para penceramah atau ustadz, yang tidak seluruhnya dapat diketahui, kecuali kegiatan itu dilaksanakan terbuka atau melibatkan kehadiran peserta dalam jumlah besar. ${ }^{46}$ Terakhir, Danur mempertanyakan mengapa komunitas Muslim tidak dapat mengorganisasikan kegiatan layanan bimbingan keagamaan seperti yang dilakukan komunitas nonMuslim di Indonesia. "Kaum Muslim tampaknya perlu belajar dari kawan-kawan Kristen untuk penyelenggaraan layanan

\footnotetext{
${ }^{44}$ Wawancara dengan Danur Lientara, Konsul Polisi pada KJRI Hong Kong, 23 Desember 2015.

${ }^{45}$ Peneliti mendapat salinan surat tersebut dari Danur Lientara, Konsul Polisi pada KJRI Hong Kong, 23 Desember 2015.

${ }^{46}$ Soal isi dari ceramah para pendakwah yang tidak seluruhnya dapat dipantau pihak KJRI Hong Kong juga menjadi perhatian Prof. Ho Wai-Yip, yang mengemuka saat wawancara peneliti dengan yang bersangkutan, 21 Desember 2015.
} 
bimbingan keagamaan yang lebih rapih dan tertata," ungkap Danur. ${ }^{47}$

\section{PENUTUP}

Dari pembahasan di atas, beberapa poin dapat dikemukakan sebagai kesimpulan. Pertama, dari segi kuantitas, komunitas Muslim Indonesia menempati porsi mayoritas dalam komunitas Muslim di Hong Kong. Hampir separuh dari komunitas Muslim di Hong Kong adalah kaum Muslim Indonesia, yang umumnya berasal dari kalangan pekerja migran yang mengisi sektor lapangan kerja pembantu rumah tangga. Namun, karena tingkat pendidikan, status sosial dan ekonomi mereka rendah, kaum Muslim Indonesia tidak memiliki daya tawar yang kuat dalam kehidupan sosial, politik dan ekonomi di Hong Kong. Kedua, dengan mempertimbangkan profil komunitas Muslim Indonesia di Hong Kong itu, yang umumnya adalah pekerja wanita dan tidak diperkenankan membawa anak atau keluarga, kebutuhan mendesak yang merekahadapiadalahlayananbimbingandan pendidikan agama bagi diri mereka sendiri, berupa layanan pendidikan keagamaan non-formal. Selama ini kebutuhan akan bimbingan pendidikan dan keagamaan itu dicoba dipenuhi lewat cara membentuk kelompok, perkumpulan atau organisasi keagamaan. Organisasi-organisasi itu umumnya tidak terdaftar sebagai organisasi resmi pada pemerintah Hong Kong. Ketiga, secara reguler mereka berupaya memenuhi

\footnotetext{
${ }^{47}$ Soal isi dari ceramah para pendakwah yang tidak seluruhnya dapat dipantau pihak KJRI Hong Kong juga menjadi perhatian Prof. Ho Wai-Yip, yang mengemuka saat wawancara peneliti dengan yang bersangkutan, 21 Desember 2015.
}

kebutuhan akan bimbingan dan pendidikan keagamaan melalui pengajian rutin yang diadakan setiap hari Minggu, sesuai waktu libur yang umumnya tersedia bagi mayoritas pekerja Indoensia. Aktivitas itu diadakan baik di kamar flat atau apartemen salah seorang pekerja migran, di masjid atau pusat Islam, atau di tempat umum, seperti taman. Cara lain pemenuhan kebutuhan itu adalah dengan mendatangkan para ustadz atau penceramah dari Indonesia. Untuk menutupi biaya, mereka mencari donasi dari berbagai pihak di Hong Kong, seperti perusahaan-perusahaan Indonesia atau KJRI, dan sebagian lainnya dengan mengenakan biaya kepada peserta. Keempat, sangat tingginya kebutuhan akan layanan bimbingan dan pendidikan keagamaan pekerja migran Indonesia di Hong Kong telah membuka peluang bagi oknum-oknum tertentu yang hendak meraup keuntungan, atau bahkan melakukan aksi penipuan, atas nama dakwah dan pembinaan keagamaan bagi komunitas pekerja migran Indonesia di Hong Kong.

Terkait dengan beberapa temuan dari penelitian ini, peneliti mengemukakan sejumlah rekomendasi sebagai berikut: Pertama, Kementerian Agama perlu menyiapkan program dalam rangka memenuhi kebutuhan pekerja migran Indonesia di Hongkong akan layanan bimbingan dan pendidikan keagamaan. Program itu dapat berupa program pembinaan keagamaan bagi calon pekerja migran selama tahap pra penempatan di luar negeri. Program ini dapat dilaksanakan bekerja sama dengan Badan Nasional Penempatan dan Perlindungan Tenaga Kerja Indonesia (BNP2TKI), yang selama ini hanya memberi pelatihan terkait keterampilan 
bagi para calon pekerja migran Indonesia. Kedua, terkait butir pertama, Kementerian Agama perlu menyiapkan program layanan bimbingan dan pendidikan agama dengan memfasilitasi pengiriman tenaga penyuluh agama atau guru agama secara berkala. Untuk jangka pendek, program itu dapat dilakukan dengan memanfaatkan visa kunjungan yang ada saat ini, sedangkan untuk jangka menengah dan panjang, Kementerian Agama perlu menjalin kerja sama $G$ to $G$ dengan Pemerintah Republik Rakyat China, melalui Kedutaan Besar China di Indonesia, agar tersedia visa khusus bagi program layanan bimbingan dan pendidikan keagamaan yang disediakan oleh pemerintah Indonesia, dalam hal ini melalui Kementerian Agama, untuk komunitas Muslim Indonesia di Hong Kong. Ketiga, Kementerian Agama, bekerja dengan pihakpihak terkait, seperti Imigrasi maupun Polri, perlu melakukan pemantauan secara berkala terhadap pihak-pihak yang selama ini berperan menjadi pemasok layanan keagamaan bagi pekerja migran Indonesia di Hong Kong maupun organisasi-organisasi yang berperan sebagai penyelenggara. Hal ini perlu dilakukan guna mengantisipasi perkembangan pandangan-pandangan keagamaan di kalangan komunitas pekerja migran di Indonesia, serta kemungkinan pengaruhnya saat mereka telah kembali ke Indonesia.

Terakhir, Kementerian Agama perlu melakukan pembicaraan dengan pihakpihak terkait, antara lain, Kementerian Luar Negeri dan Kementerian PAN-RB, mengenai kebutuhan akan keberadaan konsul agama pada KJRI, khususnya di Hong Kong. Hal itu untuk memperkuat pelaksanaan fungsi urusan agama, yang selama ini ditangani Konsul Penerangan Sosial Budaya (Pensosbud) pada KJRI. Konsul Pensosbud selama ini tampaknya terkendala dalam penanganan layanan keagamaan bagi komunitas pekerja migran Indonesia di Hong Kong karena keterbatasan tenaga atau sumber daya yang memiliki pengetahuan yang cukup terkait urusan agama.[]

\section{UCAPAN TERIMA KASIH}

Penelitian ini merupakan bagian penelitian tentang "Penyelenggaraan Pendidikan Keagamaan di Luar Negeri" yang dilaksanakan dan dibiayai anggaran Pusat PenelitianPendidikan AgamadanKeagamaan Badan Litbanng dan Diklat Kementerian Agama RI. Peneliti mengucapkan terima kasih kepada Kepala Pusat Penelitian Pendidikan Agama dan Keagamaan Dr. H.M. Hamdar Arraiyyah yang telah melibatkan peneliti dalam kegiatan penelitian tersebut. Ucapan terima kasih juga peneliti sampaikan kepada Kepala Balai Litbang Agama Jakarta Dra. Hj. Anik Farida, M.Hum yang telah merekomendasikan peneliti untuk berpartisipasi. Penliti juga mengucapkan terima kasih kepada Dr. Nurudin dan pihakpihak lain di Pusat Penelitian Pendidikan Agama dan Keagamaan Badan Litbang dan Diklat yang telah memfasilitasi penelitian ini. Peneliti juga mengucapkan terima kasih kepada Kepala Rumah Tangga Konsul Jenderal Republik Indonesia di Hong Kong Bapak Rafael Walangitan, dan juga kepada staf KJRI yang turut membantu memfasilitasi terlaksananya penelitian ini, khususnya Bapak Yolvis, Bapak Teguh Subaryanto, dan Konsul Polisi Danur Lieantara. Akhirnya peneliti juga mengucapkan terima kasih kepada seluruh narasumber penelitian ini. 


\section{DAFTAR PUSTAKA}

Bray, Mark, and Ramsey Koo (2005): .Education and Society in Hong Kong and Macao: Comparative Perspectives on Continuity and Change. Second edition. Dordrecht, Netherlands, Springer,

Connor, Peter 'O (2012): Islam in Hong Kong: Muslims and Everyday Life in China's World City. E-book. Hong Kong, Hong Kong University Press,

Erni, John Nguyet, dan Lisa Yuk-ming Leung (2014): Understanding South Asian Minorities in Hong Kong. Hong Kong, Hong Kong University Press,

$\mathrm{Fu}$, Hualing, Lison Harris, Simon N.M. Young, eds. (2007): Interpreting Hong Kong's Basic Law: The Struggle for Coherence. New York, Palgrave Macmillan

Ho, Wai-Yip. (2014): “British Raj to China's Hong Kong: The rise of madrasas for ethnic Muslim youth." Modern Asian Studies 48, 2 399-432.

Ho, Wai-Yip (2015): Islam and China's Hong Kong: Ethnic Identity, Muslim Networks, and the New Silk Road. London, Routledge

HKSAR Government Information Services Department. (2014): Hong Kong Year Book 2014. Hong Kong, Government Logistics Department,

HKSAR Government, Information Services Department (2013): Hong Kong Year Book 2013. Hong Kong, Government Logistics Department

\section{Daftar Informan}

Abdul Muhaemin Karim, Da'wah Executive pada Islamic Union of Hong Kong, 19 Desember 2015.

Danur Lientara, Konsul Polisi pada KJRI Hong Kong, 23 Desember 2015.

Ghazali, staf KJRI Hong Kong, 19 Desember 2015.

Mursingah, pekerja migran dan koordinator Majelis Taklim Roudhotul Jannah di Tsuen Wen, 20 Desember 2015.

Nining Haryani, pekerja migrandan koordinator Persatuan Islam Indonesia, 20 Desember 2015.

Rafael Walangitan, kepala rumah tangga KJRI Hong Kong, 22 Desember 2015.

Rikna Dewi, koordinator LPTQ Dompet Dhuafa Hong Kong, 20 Desember 2015.

Rovi Octaviano Vustany, General Manager Dompet Dhuafa Hong Kong, 22 Desember 2015.

Teguh Subaryanto, staf KJRI Hong Kong, 19 Desember 2015.

Tri Puji, koordinator Jami'atu Sakinah di Tsim Sha Tsui, Kowloon, 20 Desember 2015.

Wai-Yip Ho, dosen sosiologi pada Hong Kong Institute of Education, Tai Po, 21 Desember 2015.

Yolvis, staf pada konsul Pensosbud KJRI Hong Kong, 18 Desember 2015; 